San Jose State University

SJSU ScholarWorks

4-1999

\title{
Combined Microautoradiography-16S rRNA Probe Technique for Determination of Radioisotope Uptake by Specific Microbial Cell Types In Situ
}

\author{
Cleber C. Ouverney \\ University of Southern California, cleber.ouverney@sjsu.edu \\ Jed A. Fuhrman \\ University of Southern California
}

Follow this and additional works at: https://scholarworks.sjsu.edu/biol_pub

\begin{abstract}
Recommended Citation
Cleber C. Ouverney and Jed A. Fuhrman. "Combined Microautoradiography-16S rRNA Probe Technique for Determination of Radioisotope Uptake by Specific Microbial Cell Types In Situ" Faculty Publications, Biological Sciences (1999): 1746-1752.
\end{abstract}

This Article is brought to you for free and open access by the Biological Sciences at SJSU ScholarWorks. It has been accepted for inclusion in Faculty Publications, Biological Sciences by an authorized administrator of SJSU ScholarWorks. For more information, please contact scholarworks@sjsu.edu. 


\title{
Combined Microautoradiography-16S rRNA Probe Technique for Determination of Radioisotope Uptake by Specific Microbial Cell Types In Situ
}

\author{
CLEBER C. OUVERNEY* AND JED A. FUHRMAN \\ Department of Biological Sciences, University of Southern California, Los Angeles, California 90089-0371
}

Received 13 October 1998/Accepted 22 December 1998

\begin{abstract}
We propose a novel method for studying the function of specific microbial groups in situ. Since natural microbial communities are dynamic both in composition and in activities, we argue that the microbial "black box" should not be regarded as homogeneous. Our technique breaks down this black box with group-specific fluorescent $16 \mathrm{~S}$ rRNA probes and simultaneously determines ${ }^{3} \mathrm{H}$-substrate uptake by each of the subgroups present via microautoradiography (MAR). Total direct counting, fluorescent in situ hybridization, and MAR are combined on a single slide to determine (i) the percentages of different subgroups in a community, (ii) the percentage of total cells in a community that take up a radioactively labeled substance, and (iii) the distribution of uptake within each subgroup. The method was verified with pure cultures. In addition, in situ uptake by members of the $\alpha$ subdivision of the class Proteobacteria ( $\alpha$-Proteobacteria) and of the Cytophaga-Flavobacterium group obtained off the California coast and labeled with fluorescent oligonucleotide probes for these subgroups showed that not only do these organisms account for a large portion of the picoplankton community in the sample examined ( $\sim 60 \%$ of the universal probe-labeled cells and $\sim 50 \%$ of the total direct counts), but they also are significant in the uptake of dissolved amino acids in situ. Nearly $90 \%$ of the total cells and $80 \%$ of the cells belonging to the $\alpha$-Proteobacteria and Cytophaga-Flavobacterium groups were detectable as active organisms in amino acid uptake tests. We suggest a name for our triple-labeling technique, substrate-tracking autoradiographic fluorescent in situ hybridization (STARFISH), which should aid in the "dissection" of microbial communities by type and function.
\end{abstract}

In situ characterization of the marine picoplankton "black box" has been restricted mostly to determinations of community composition by a number of molecular techniques, including fluorescent in situ hybridization (FISH) $(2,3,13,16,18$, 33). In FISH fluorescently labeled oligonucleotide rRNA probes are used to identify and enumerate microorganisms in situ $(13,16)$. Probe sequences can target organisms at various taxonomic levels. Some probes are universal and target all organisms $(18,32)$, while others are for the domains Archaea $(17,30,35)$ and Bacteria $(16,18)$; other probes target intermediate levels, such as the $\alpha$ subdivision of the class Proteobacteria $(\alpha$-Proteobacteria), $\beta$-Proteobacteria, and $\gamma$-Proteobacteria (29), as well as the Cytophaga-Flavobacterium group (28); and still other probes are specific for species and subspecies (37).

In addition to composition, the marine bacterioplankton community can be characterized by its ecological role in the uptake of dissolved organic matter (DOM) via autoradiography $(6,15,24,38)$. Workers have reported that the bacterioplankton may be responsible for transferring up to 50 to $60 \%$ of the local primary production from the DOM pool into higher trophic levels through the microbial loop $(7,14,15,20)$. Standard measurements of in situ nutrient uptake, however, do not discriminate between different prokaryotic groups. Since analysis of $16 \mathrm{~S}$ rRNA sequences shows that the marine picoplankton community is dynamic and is composed of various diverse organisms $(3,36)$, while studies of nutrient uptake by pure cultures show that the type and rate of nutrient uptake vary among different strains (22), we can conclude that in situ

\footnotetext{
* Corresponding author. Mailing address: Department of Biological Sciences, University of Southern California, Los Angeles, CA 900890371. Phone: (213) 740-5759. Fax: (213) 740-8123. E-mail: ouverney @usc.edu.
}

substrate uptake is dependent on the local picoplankton community composition. Hence, in order to better understand and model DOM uptake in the ocean, microbiologists need to "dissect" the bacterioplankton black box into smaller compartments on the basis of taxonomy and function instead of looking at it as a single homogeneous group.

In situ identification of the different prokaryotic groups in mixed communities, however, is limited by the lack of morphological features (9); this is the prime reason why FISH has become such an important tool in microbial ecology (3). Also, isolation of marine prokaryotes in pure cultures has been demonstrated to be difficult; less than $1 \%$ of the total natural community grows under laboratory conditions (39).

Here we suggest a new method in which FISH and microautoradiography are combined to determine in situ nutrient uptake by members of specific picoplankton groups on a single slide. The cells are triple-labeled with a general stain, a fluorescent oligonucleotide probe, and a tritiated substrate. With the same microscopic field it is possible to determine not only the percentage of a specific prokaryotic phylogenetic group in a mixed sample but also the distribution of nutrient uptake within each subgroup. Results obtained with both mixed cultures and natural marine samples are presented below.

\section{MATERIALS AND METHODS}

The sequence of events in our triple-labeling technique involved collection of samples, transfer of cells onto emulsion-gelatin-coated slides, emulsion exposure and development, whole-cell hybridization, and epifluorescence counting. All solutions, including the culture media and phosphate-buffered saline (PBS), were filtered with $0.2-\mu \mathrm{m}$-pore-size Nuclepore filters, autoclaved, and checked for the presence of prokaryotes by DAPI (4',6-diamidino-2-phenylindole) staining before they were used throughout the entire procedure. Formalin was filtered with $0.02-\mu \mathrm{m}$-pore-size Whatman Anodisc filters before it was used.

Culture preparation. The following organisms were selected based on their uptake of glucose and morphological characteristics for easy differentiation in 
TABLE 1. Probe sequence used for FISH

\begin{tabular}{|c|c|c|c|}
\hline Target & Sequence $\left(5^{\prime}-3^{\prime}\right)^{a}$ & Probe name ${ }^{b}$ & $\overline{\text { Reference }}$ \\
\hline Control (no group) ${ }^{c}$ & CCTAGTGACGCCGTCGAC & Control & 32 \\
\hline Universal & GWATTACCGCGGCKGCTG & S-*-Univ-0519-a-A-18 & $24 \mathrm{a}$ \\
\hline Bacteria & ACCGCTTGTGCGGGCCC & S-Bact-0927-b-A-17 & 18 \\
\hline$\alpha$-Proteobacteria & CGTTCGYTCTGAGCCAG & S-Sc-aProt-0019-a-A-17 & 29 \\
\hline Cytophaga-Flavobacterium group & TGGTCCGTRTCTCAGTAC & S-*-CF-0319-a-A-18 & 3 \\
\hline
\end{tabular}

${ }^{a} \mathrm{~W}=\mathrm{A}$ or $\mathrm{T} ; \mathrm{Y}=\mathrm{C}$ or $\mathrm{T} ; \mathrm{R}=\mathrm{A}$ or $\mathrm{G}$.

${ }^{b}$ Probe names based on names in the Oligonucleotide Probe Database (31a).

${ }^{c}$ There were more than three mismatches compared with all of the rRNA sequences in the RDP database, and there was no appropriate Oligonucleotide Probe Database name.

nutrient uptake tests and during identification by epifluorescence microscopy and on photomicrographs: Escherichia coli, a short bacillus which can take up glucose; and Moraxella catarrhalis, a coccus (whose cells usually occur in pairs) that does not take up glucose (22). The two main purposes of the culture experiment were to test the protocol under highly controlled conditions and to test whether 16S rRNA, the target molecule for the oligonucleotide probes, could endure the conditions in the photographic solutions.

Replicates of both cultures were grown separately in Luria-Bertani enriched medium at $37^{\circ} \mathrm{C}$ to the mid-exponential growth phase, as determined with a Klett colorimeter (Klett-Summerson, New York, N.Y.) at an optical density of $525 \mathrm{~nm}$. Cells were concentrated by centrifugation at $2,300 \times g$ at $17^{\circ} \mathrm{C}$ for $5 \mathrm{~min}$ and were washed three times in $1 \times$ PBS; this was followed by two additional centrifugation steps, and each time the cells were resuspended in M9 minimal medium (27) lacking glucose.

Natural sample preparation. The following natural samples were collected in 250-ml acid-washed dark bottles from two sites in southern California: (i) Catalina Island surface water, which was collected on 16 January 1998 at $33^{\circ} 26.71^{\prime} \mathrm{N}$ and $118^{\circ} 29.07^{\prime} \mathrm{W}$; and (ii) water collected in the San Pedro Channel $5 \mathrm{~m}$ below the surface on 31 May 1998 at $33^{\circ} 33^{\prime} \mathrm{N}$ and $118^{\circ} 24^{\prime} \mathrm{W}$.

Sample treatment. Tritiated D-glucose (Dupont) was added at a concentration of $10 \mathrm{nM}$ to two replicate cultures growing in minimal medium. Two killed controls for each culture were prepared by treatment with $10 \%$ formalin for $1 \mathrm{~h}$ prior to addition of $\mathrm{D}-\left[{ }^{3} \mathrm{H}\right]$ glucose. Cultures were incubated on a rotary shaking platform at $250 \mathrm{rpm}$ at $37^{\circ} \mathrm{C}$.

Natural samples were divided into four $40-\mathrm{ml}$ subsamples in sterile conical tubes. Two of the subsamples that were killed by treatment with $10 \%$ formalin for $1 \mathrm{~h}$ served as controls. All four subsamples were supplemented with a $5 \mathrm{nM}$ ${ }^{3} \mathrm{H}$-amino acid mixture (Amersham) and were incubated at in situ seawater temperatures.

Nutrient uptake was monitored over time for all of the live and killed cultures, as well as for the natural subsamples, by withdrawing $2-\mathrm{ml}$ aliquots from each culture or subsample, filtering the aliquots onto a $0.2-\mu \mathrm{m}$-pore-size $25-\mathrm{mm}$ diameter Nuclepore polycarbonate filter, rinsing the filter four times with about $2 \mathrm{ml}$ of $1 \times \mathrm{PBS}$, and measuring the radioactivity with a scintillation counter by using EcoscintA scintillation cocktail (National Diagnostic, Atlanta, Ga.). The cell concentration was determined with DAPI (34), and the uptake of nutrients was terminated by adding formalin to a concentration of $10 \%$ when live samples reached saturation levels of radioactivity. Equal numbers of cells from E. coli and M. catarrhalis cultures were combined in $15-\mathrm{ml}$ polycarbonate tubes prior to slide preparation.

Slide preparation. In a darkroom, a photographic emulsion (type NTB2; Kodak, Rochester, N.Y.) was melted for $1 \mathrm{~h}$ at $43^{\circ} \mathrm{C}$ in a water bath and then mixed with a $43^{\circ} \mathrm{C}$ gelatin solution $(0.2 \%$ [final concentration] gelatin, $0.02 \%$ [final concentration] $\mathrm{CrKSO}_{4}$ ) at a 50:50 (vol/vol) ratio. Using an ITT (Roanoke, Va.) Night Vision scope and a $15-\mathrm{W}$ safelight (model $5^{1 / 2}$; Testrine Instrument, Newark, N.J.) placed $2 \mathrm{~m}$ away, we coated heavy Teflon glass slides with 10 7-mm-diameter wells (Cel-Line Associates, Inc., Newfield, N.J.) with the emulsion-gelatin solution. The wells on the slides were coated separately by dispensing approximately $20 \mu \mathrm{l}$ of the emulsion-gelatin solution into each well and immediately withdrawing as much as possible with a micropipette. Coating wells separately was necessary to keep Teflon areas around the wells hydrophobic, which prevented the hybridization buffer (see below) in one well from merging with the buffer in adjacent wells. Also, if the emulsion was not mixed with gelatin, the emulsion tended to peel off the glass slide during emulsion development or during in situ hybridization (see below). Three slides were coated with the emulsion-gelatin solution at a time and were left to dry for $30 \mathrm{~min}$ in total darkness while filters with samples were being prepared. This minimized the background exposure of the emulsion in wells. The emulsion was kept in total darkness unless it was used.

Attempts to transfer cells to Teflon slides coated with gelatin followed by in situ hybridization and then by coating the slides with the NTB2 emulsion resulted in very low fluorescence signals from both DAPI and the probes.

Whole-cell prestaining and filtration. Under room light, $10-\mu l$ portions of a formalin-fixed culture containing $6.74 \times 10^{7}$ cells $/ \mathrm{ml}$ were added to $5 \mathrm{ml}$ of $1 \times$ PBS in clean stainless steel filtration towers and filtered down to a volume of 2 $\mathrm{ml}$ onto a $0.2-\mu \mathrm{m}$-pore-size 25 -mm-diameter Nuclepore polycarbonate filter placed over a $0.8-\mu \mathrm{m}$-pore-size type AA Millipore filter. For the natural samples $10 \mathrm{ml}$ of the formalin-fixed Catalina Island sample $\left(3.32 \times 10^{6}\right.$ cells $\left./ \mathrm{ml}\right)$ or the San Pedro Channel sample $\left(6.74 \times 10^{5}\right.$ cells $\left./ \mathrm{ml}\right)$ was used and also filtered to 2 $\mathrm{ml}$. The cells in the $2-\mathrm{ml}$ preparation were then stained with $100 \mu \mathrm{l}$ of a $0.1-\mu \mathrm{g} / \mu \mathrm{l}$ DAPI solution for $10 \mathrm{~min}$ in the dark (obtained by covering the filtration towers with aluminum foil) before the filtration was completed. All of the filters were then rinsed four times with about $2 \mathrm{ml}$ of $1 \times$ PBS to remove unincorporated radioactive glucose or amino acid. With clean forceps, the Nuclepore and Millipore filters were placed together with the cell side facing up on a 10- $\mu$ l drop of $1 \times$ PBS in a petri dish, cut into eight equal pieces with a new razor blade, and carried to the darkroom, where they were transferred to Teflon slides that had been precoated with the emulsion-gelatin solution. Only three filters were prepared at a time to prevent the filters from drying out before they were transferred to the emulsion-gelatin-coated slides in the darkroom. Prestaining of cells with DAPI did not result in any noticeable increase in the background silver grain on the emulsion like that reported by Carman (11) when cells were prestained with acridine orange.

Cell transfer to slides, emulsion exposure, and development. The method used to transfer cells to slides was similar to the microautoradiogram method (version E) by Tabor and Neihof (41). Cells were immediately transferred from the filter to a Teflon-coated slide by peeling each of the eight sections of the $0.2-\mu \mathrm{m}$ Nuclepore filter off the $0.8-\mu \mathrm{m}$-pore-size Millipore filter in the darkroom and placing it upside down (with the cells facing down) onto a single well coated with the emulsion-gelatin solution. The safelight was placed $2 \mathrm{~m}$ away during cell transfer, and the ITT Night Vision scope was used. The slides were left to dry in total darkness for $30 \mathrm{~min}$ before they were placed in a light-proof box which was wrapped in aluminum foil, placed inside a cardboard box, and stored at $4^{\circ} \mathrm{C}$ for 3 days for emulsion exposure. The emulsion was developed by using Kodak specifications, as follows: $2 \mathrm{~min}$ in Dektol developer, 10-s stop in deionized water, and $5 \mathrm{~min}$ in fixer. The slides were washed in deionized water for $2 \mathrm{~min}$, the pieces of the Nuclepore filters were peeled off, and the slides were dried and prepared for whole-cell hybridization. At this point, the slides could be stored at $-80^{\circ} \mathrm{C}$ for several weeks without noticeable changes in the results.

In situ hybridization. The procedures used for cell hybridization were the procedures which we described previously (32). Oligonucleotide probes were modified with amino linkers attached at both the $3^{\prime}$ and $5^{\prime}$ termini (Operon Technologies, Inc., Alameda, Calif.) and labeled with cyanine Cy3 monofunctional dye (Amersham) in $0.1 \mathrm{M}$ carbonate buffer ( $\mathrm{pH} 8.5$ ) overnight in the dark at room temperature (19). The method used to separate labeled probes from unlabeled probes was a modification of the method of Amann et al. (2). Briefly, the steps used to purify labeled probes included separating the oligonucleotides from the unreacted Cy3 dye in an STE Select-D G-25 spin column (5'-3' Prime, Boulder, Colo.). The labeled probes were then separated from the unlabeled probes in a $20 \%$ nondenaturing polyacrylamide gel, and the bands containing Cy3-labeled oligonucleotides were visualized on the gel with a hand-held 254-nm UV lamp (model EF-160c; Spectronics Inc., Westbury, N.Y.). The top labeled band was cut out of the gel, and the probe was eluted in low TE $(10 \mathrm{mM}$ Tris-hydrochloride, $1 \mathrm{mM}$ EDTA; $\mathrm{pH} 7.8$ ) at $4^{\circ} \mathrm{C}$. The eluted solution was then passed through Nensorb-20 columns (Du Pont, Wilmington, Del.) as described by the manufacturer. The amount of labeled probe was determined by absorbance at $260 \mathrm{~nm}$. The probes were lyophilized and stored dry at $-80^{\circ} \mathrm{C}$. The probes used for the various samples included a negative control probe $(\mathrm{CON})$, which was not expected to bind to any organism; a universal probe (UNI), which was expected to bind to all organisms; a probe of the domain Bacteria (BAC); and probes for two of the subgroups of the domain Bacteria, a probe for the $\alpha$-Proteobacteria $(\alpha \mathrm{PRT})$ and a probe for the Cytophaga-Flavobacterium cluster of the Cytophaga-Flavobacterium-Bacteroides phylum (CF). Table 1 shows the probe sequences, $E$. coli positions, and references.

In situ hybridization took place in buffer containing $5 \times$ SET $(1 \times$ SET is 150 $\mathrm{mM} \mathrm{NaCl}, 20 \mathrm{mM}$ Tris-HCl [pH 7.8], and $1 \mathrm{mM}$ EDTA), $0.2 \%$ bovine serum albumin (acetylated; Sigma), 10\% dextran sulfate (molecular weight, 500,000; Pharmacia), $0.01 \%$ polyadenylic acid (Sigma), and $0.1 \%$ sodium dodecyl sulfate as described by DeLong et al. (13) and Braun-Howland et al. (8); the probe concentration was $5 \mathrm{ng}_{\mu \mathrm{l}}^{-1}$. The slides were incubated at $43^{\circ} \mathrm{C}$ for 3 to $16 \mathrm{~h}$, 

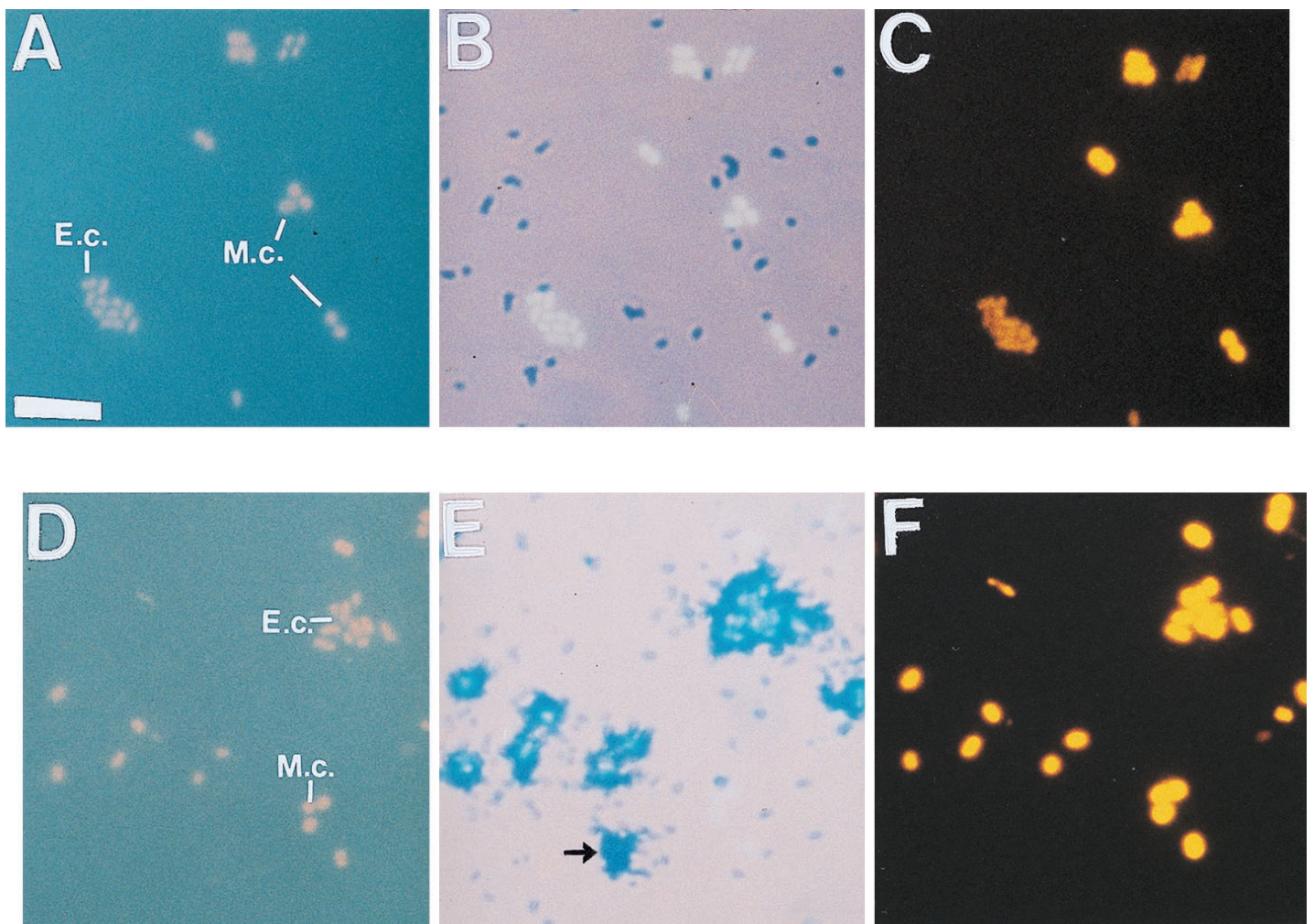

FIG. 1. Triple-labeling of mixed E. coli and M. catarrhalis cells radiolabeled with D- $\left[{ }^{3} \mathrm{H}\right]$ glucose in M9 minimal medium for killed control samples (A through C) and live samples (D through F). (A and D) DAPI-labeled E. coli cells (short bacilli) (E.c.) and M. catarrhalis cells (cocci) (M.c.) with UV excitation. (B and E) Microautoradiograms showing no D- $\left[{ }^{3} \mathrm{H}\right]$ glucose uptake (B) or D- $\left[{ }^{3} \mathrm{H}\right]$ glucose uptake only by E. coli cells (E). (C and F) Cy3-conjugated Bacteria probe-labeled cells. The arrow in panel E indicates a silver grain, and no corresponding cell occurred in either the DAPI-stained (D) or probe (F) field; silver grains occurred in less than $2 \%$ of the ${ }^{3} \mathrm{H}$-labeled cells (see text). Bar $=5 \mu \mathrm{m}$.

briefly rinsed with distilled water at $43^{\circ} \mathrm{C}$, and finally immersed three times in $0.2 \times \mathrm{SET}$ at $43^{\circ} \mathrm{C}$ for $10 \mathrm{~min}$ each time. After air drying, the slides were mounted in a glycerol-10 $\times$ SET (50:50, vol/vol) solution and kept at $-20^{\circ} \mathrm{C}$ for at least $1 \mathrm{~h}$ before they were observed by fluorescence and transmitted light microscopy.

Autoradiographic and fluorescent-cell counts. For each microscopic field, the following four types of counts were obtained: (i) total DAPI cell counts with UV excitation (Olympus type U-MWU UV filter; excitation wavelength, 330 to 385 $\mathrm{nm}$; emission wavelength, $>420 \mathrm{~nm}$ ); (ii) probe fluorescence cell counts, which included autofluorescent and probe-labeled cell counts with green light excitation (Chroma type tetramethylrhodamine isothiocyanate [TRITC] U-M41002 filter; excitation wavelength, $535 \pm 50 \mathrm{~nm}$; emission wavelength, $565 \mathrm{~nm}$ ); (iii) microautoradiography counts (cells labeled with one of the tritiated nutrients) under transmitted light; and (iv) counts for cells labeled with a fluorescent probe and simultaneously labeled autoradiographically (overlap between green excitation and transmitted light). The last three types of counts were computed as percentages of the total DAPI cell counts.

All counts were obtained within 2 days of hybridization by using an Olympus Bmax epifluorescence microscope equipped with a UPlanApo objective lens (magnification, $\times 100$ ), a type $\mathrm{HBO} 100 \mathrm{Hg}$ vapor lamp, and the filters described above. The images were captured and intensified by using a microchannel plate image intensifier (model COHU intensified charge-coupled device camera), and the background was reduced by image averaging with a model DSP-2000 image processor (Dage-MTI, Inc., Michigan City, Ind.). The images were visualized with a Sony Trinitron color video monitor (model PVM-1353MD). This video system could display cells with fluorescence considerably less than the fluorescence directly detectable by eye.

Comparing counts with FISH counts. In order to determine whether the treatment of cells during the triple-labeling technique protocol had any effect on the natural picoplankton community composition (from selective transfer of cells to or selective loss of cells from the emulsion-coated slides), the fluorescent probe counts obtained from the triple-labeling experiments were compared to standard FISH counts obtained for the San Pedro Channel sample collected on 31 May 1998. The standard FISH protocol used has been described in detail previously (32), and no chloramphenicol treatment was performed before the cells were preserved.

Photomicrography. Culture samples were photographed with the Olympus Bmax microscope described above by using Fujifilm Provia 1600 ISO film. The exposure times were $5 \mathrm{~s}$ with UV excitation (DAPI-stained cells), about $1 \mathrm{~min}$ with green excitation (probe-labeled and autofluorescent cells), and $3 \mathrm{~s}$ with transmitted light (autoradiographically labeled cells). The oligonucleotide probe fluorescence from some cells in the natural sample was too dim (compared to that of the intensified video system) to be properly recorded on the photographic film.

\section{RESULTS}

Cultures. The results of the culture experiment were as expected. From the nutrient uptake curves, we confirmed that the $E$. coli strain used was capable of taking up glucose but that the $M$. catarrhalis strain was not. When these strains of $E$. coli (short bacilli in Fig. 1) and M. catarrhalis (cocci in Fig. 1) were used in the triple-labeling experiment, the autoradiography counts showed an all-or-nothing type of results. While $100 \%$ of the live $E$. coli cells were labeled with $\left[{ }^{3} \mathrm{H}\right]$ glucose (compare the short bacilli in Fig. 1D with the autoradiographic marks at the same positions in Fig. 1E), the $M$. catarrhalis cells remained unlabeled (compare the cocci in Fig. 1D with the autoradiographic marks at the same positions in Fig. 1E). None of the killed cells in the control samples took up $\left[{ }^{3} \mathrm{H}\right]$ glucose (Fig. 1A and $1 \mathrm{~B}$ ).

Less than $2 \%$ of cells left an autoradiographic record on the emulsion (Fig. 1E) without a corresponding attached cell (Fig. 1D). The silver grain marks left by labeled cells were distinct in shape and size. It is also possible that cells were washed off the emulsion during in situ hybridization, but no tests were done to confirm this.

When cells were excited under green light, none of the cells were visible with no probe (NP) or with the control probe 


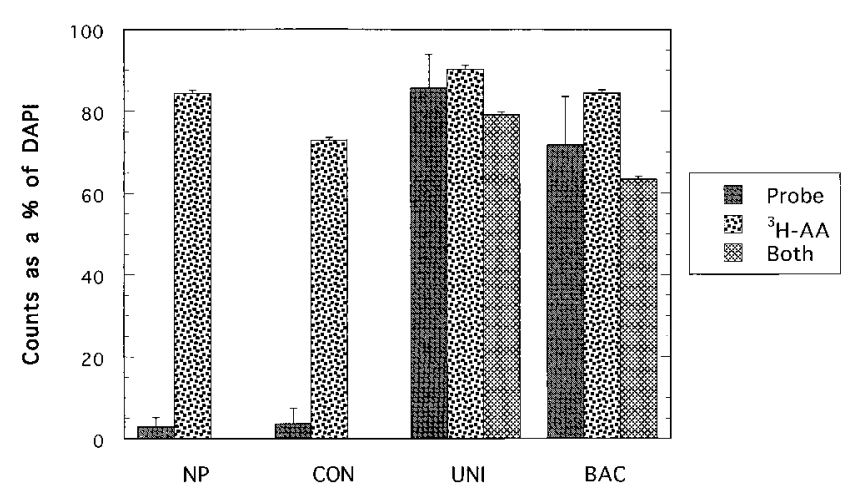

FIG. 2. Fluorescent-oligonucleotide probe, ${ }^{3} \mathrm{H}$-amino acid mixture, and probe plus ${ }^{3} \mathrm{H}$-amino acid mixture counts as percentages of the total DAPI counts for the Catalina Island (30 km off the coast of Los Angeles) surface sample collected on 16 January 1998. All of the probes, including the control (CON), universal (UNI), and Bacteria domain (BAC) probes, were dually labeled with $\mathrm{Cy} 3$ dye. Autofluorescent cell counts were not subtracted from the probe counts. The error bars indicate standard errors. ${ }^{3} \mathrm{H}-\mathrm{AA},{ }^{3} \mathrm{H}$-labeled amino acids.

$(\mathrm{CON})$, while all of the cells were visible with the universal probe (UNI) or with the Bacteria probe (BAC) (compare the probe-labeled cells in Fig. $1 \mathrm{C}$ and $\mathrm{F}$ with the corresponding DAPI-labeled cells in Fig. 1A and B, respectively).

Natural marine samples. Tritiated amino acid uptake curves for both of the marine samples revealed rapid uptake that reached the saturation level by $3 \mathrm{~h}$. The final corrected levels of radioactivity (live-cell radioactivity minus killed-cell radioactivity) for these two samples were of the same order of magnitude, but the value for the Catalina Island sample $(3.14 \times$ $10^{-2} \mathrm{dpm} /$ cell or $2.8 \times 10^{-19} \mathrm{~mol}$ of ${ }^{3} \mathrm{H}$-amino acid/cell) was two times higher than the value for the San Pedro Channel sample $\left(1.53 \times 10^{-2} \mathrm{dpm} / \mathrm{cell}\right.$ or $1.4 \times 10^{-19} \mathrm{~mol}$ of ${ }^{3} \mathrm{H}$-aminoacid/cell). The levels of radioactivity for the killed controls were nearly undetectable $\left(5.6 \times 10^{-5} \mathrm{dpm} /\right.$ cell for the Catalina Island sample control and $8.0 \times 10^{-5} \mathrm{dpm} /$ cell for the San Pedro Channel sample control).

Triple-labeling data confirmed that the killed controls did not take up the ${ }^{3} \mathrm{H}$-amino acid mixture when either the Catalina Island sample for (Fig. 2) or the San Pedro Channel sample (Fig. 3) was examined. The 3 to $4 \%$ live cells detected for either the NP counts $(2.8 \%)$ or the CON probe counts $(3.5 \%)$ with the Catalina Island sample were assumed to be

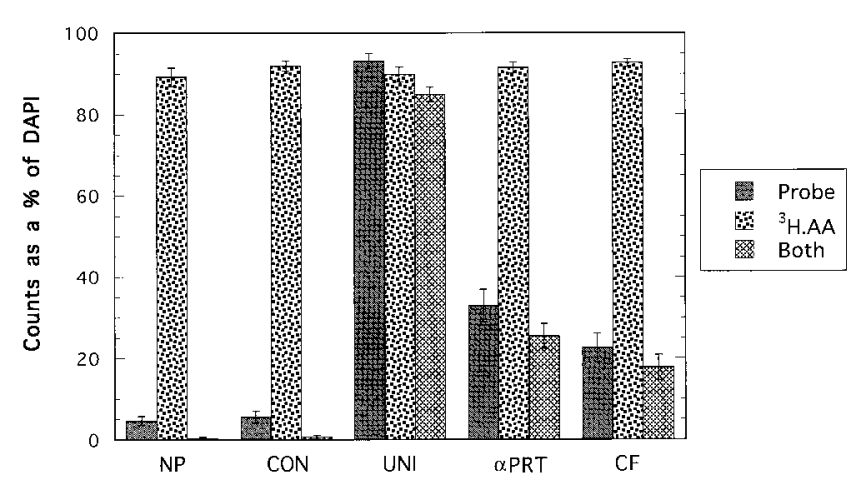

FIG. 3. Same as Fig. 2, except that the $\alpha$-Proteobacteria $(\alpha \mathrm{PRT})$ and Cytophaga-Flavobacterium (CF) probes were used instead of the BAC probe for the San Pedro Channel surface sample collected on 31 May 1998. The error bars indicate standard errors. ${ }^{3} \mathrm{H}$-AA, ${ }^{3} \mathrm{H}$-labeled amino acids.

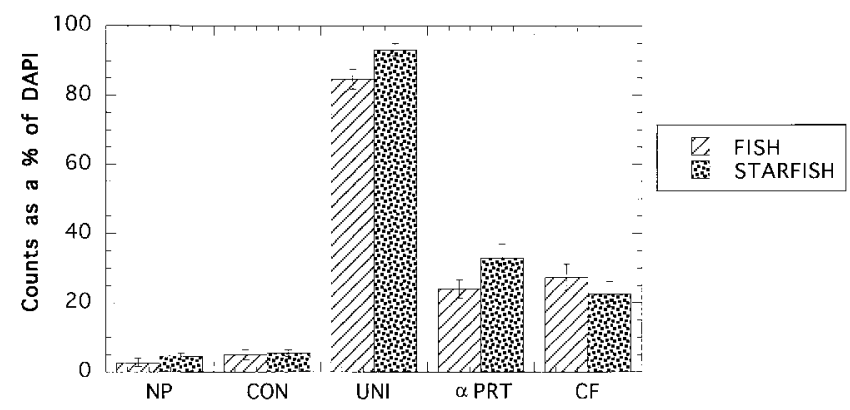

FIG. 4. Comparison between FISH and STARFISH NP, control (CON), universal (UNI), $\alpha$-Proteobacteria ( $\alpha$ PRT), and Cytophaga-Flavobacterium $(\mathrm{CF})$ probe counts as percentages of total DAPI counts for the San Pedro Channel sample collected on 31 May 1998. The error bars indicate standard errors.

autofluorescent counts that probably originated from chlorophyll and phycoerythrin pigments, and they were not detected autoradiographically (Fig. 2). Autofluorescent cells are probably autotrophic, and they did not seem to take up dissolved amino acids in this experiment. With the San Pedro Channel sample the NP or CON probe counts accounted for less than $6 \%$ of the live cells, and less than $1 \%$ of the cells were simultaneously labeled with probe and by autoradiography (Fig. 3). The differences between the killed and live subsample probe (and NP) counts were not significant for either the Catalina Island sample ( $P=0.278$, as determined by Student's $t$ test) or the San Pedro Channel sample $(P=0.128$, as determined by Student's $t$ test).

The average overall percentage of cells labeled autoradiographically (average autoradiography counts as percentages of DAPI counts for all probe and NP preparations) for the live Catalina Island subsample was $83 \%$ (standard error, $\pm 3.62 \%$ ) (autoradiography counts divided by DAPI counts) (Fig. 2). The percentage was slightly higher for the San Pedro Channel sample (Fig. 3), 91\% (standard error, $\pm 0.6 \%$ ). Counts for the Catalina Island sample when cells were simultaneously labeled autoradiographically and with fluorescent probe showed that nearly $80 \%$ (standard error, $\pm 4.0 \%$ ) of all of the cells were labeled with the universal probe (UNI) and ${ }^{3} \mathrm{H}$-amino acids and $64 \%$ (standard error, $\pm 4.0 \%$ ) of the cells were labeled with the Bacteria probe (BAC) and ${ }^{3} \mathrm{H}$-amino acids.

The following two Bacteria subgroup-specific probes were used for the San Pedro Channel sample instead of the BAC probe: the $\alpha$-Proteobacteria probe $(\alpha \mathrm{PRT})$ (mean \pm standard error, $33 \pm 4 \%)$ and Cytophaga-Flavobacterium probe (CF) (mean \pm standard error, $23 \pm 3.5 \%$ ). Labeled amino acid uptake with each of these group-specific probes (computed as the simultaneous probe and autoradiography counts divided by the probe count, including the autofluorescent cell count) showed that $77 \%$ of the cells in the San Pedro Channel sample were labeled with the $\alpha$ PRT probe and $78 \%$ of the cells labeled with the CF probe were also labeled autoradiographically with the amino acid mixture (Fig. 3).

A comparison between the triple-labeling technique and the FISH technique for the San Pedro Channel sample (Fig. 4) showed that there were no significant differences $(P=0.253$, as determined by the Student $t$ test) for the NP counts and for all four probe (CON, UNI, $\alpha \mathrm{PRT}$, and $\mathrm{CF}$ ) counts.

\section{DISCUSSION}

Our results show that it is possible to obtain simultaneous in situ measurements for the composition of a bacterioplankton 
community and the capacity of the community to take up specific organic nutrients. Culture experiments in which $E$. coli and $M$. catarrhalis strains were mixed helped demonstrate the feasibility of the triple-labeling technique. Under these highly controlled conditions, culture experiments showed that it is possible to label cells with fluorescent probes even after the cells undergo the additional treatments of the triple-labeling technique. In addition, the culture experiments provided a simple example of one of the applications of the triple-labeling technique. Both E. coli and M. catarrhalis belong to the domain Bacteria, but only E. coli was capable of taking up glucose, supporting our previous statement that in mixed picoplankton communities nutrient uptake is dependent on the local community composition.

Furthermore, results obtained with the triple-labeling technique did not differ significantly from results obtained with FISH alone $(P>0.05)$ despite the lengthier procedures involved in the former protocol. Hence, any loss of cells from the emulsion-coated slides due to the additional rinse steps or during the development of the emulsion in the triple-labeling technique did not lead to a significant change in the apparent community composition.

Although the oligonucleotide probes used in our study targeted the entire domain Bacteria and two of its subgroups, the $\alpha$-Proteobacteria and the Cytophaga-Flavobacterium group, other workers have used more group-specific probes (including probes specific at the species level) for in situ studies of mixed microbial communities $(3-5,42)$. In addition, the tritiated amino acid mixture used in our experiments served as an unspecialized label for easily labeling most or all heterotrophically active organisms. However, more specific substrates, such as simple sugars, polymers, nucleosides, phospholipids, or dissolved inorganic ions, could be used.

With the Catalina Island sample, the Bacteria probe tagged almost all of DAPI-labeled cells, and most of these cells took up detectable levels of amino acids, suggesting that members of most Bacteria subgroups contribute to the uptake of dissolved amino acids at this site. The results obtained with the more specific probes for the San Pedro Channel sample showed that cells labeled with the $\alpha$-Proteobacteria probe $(\alpha \mathrm{PRT})$ and the Cytophaga-Flavobacterium probe (CF) combined accounted for almost $60 \%$ of all of the cells labeled with the UNI probe $[(\alpha \mathrm{PRT}+\mathrm{CF}) / \mathrm{UNI}]$ at that site, assuming that there was no nontarget labeling that resulted in overlap between the two subgroup probes. Such results agree with previous findings which showed that most clones recovered in nearby waters belonged to members of these subgroups (12, 17). Furthermore, most of the cells of members of each of the subgroups ( $80 \%$ of each subgroup) were active in uptake of dissolved amino acids.

It is important to note that probe counts probably underestimate the total number of cells belonging to the probe target group for a given natural sample for two important reasons. First, some naturally occurring prokaryotes seem to have insufficient 16S rRNA for them to be detectable by whole-cell fluorescent hybridization $(23-25,32)$. These cells may grow too slowly $(1,13,21)$, or they may be inactive (43). In contrast to the results of Zweifel and Hagström (43), who found that up to $70 \%$ of the cells in the Baltic Sea were inactive, the numbers of inactive cells in our samples ranged from 7 to $15 \%$ of the total cells based on probe counts. Furthermore, we showed previously (32) that treatment of natural samples with chloramphenicol at a concentration of $100 \mu \mathrm{g} / \mathrm{ml}$ for $1 \mathrm{~h}$ can increase the level of detection of prokaryotes with a universal fluorescent probe by $15 \%$ on average to about $95 \%$ of the total counts. Although we could not pretreat our samples with chlor- amphenicol in this study because this antibiotic stops amino acid incorporation, it should be possible to treat samples after uptake is completed.

A second reason for the possible underestimation of the probe counts is related to the fact that the $16 \mathrm{~S}$ rRNA sequences of only a small portion of the total community have been determined and most likely the probe sequences available do not perfectly match all members of the target groups. Furthermore, because new probe sequences are added to ribosomal databases daily, probes should be checked frequently. Brunk et al. (10) analyzed the specificity of the Bacteria probe used here and reported that it bound to $92 \%$ of all Bacteria sequences in the Ribosomal Database Project (RDP) database (26) when 1,484 Bacteria sequences were available. An analysis of the same probe has not been performed with the updated version of the RDP database (9a), which currently contains 5,952 Bacteria sequences (26).

Even though it was not the purpose of this work to evaluate the previously described probe sequences used in our experiments, a preliminary probe check analysis of the RDP database with the $\alpha \mathrm{PRT}$ and $\mathrm{CF}$ probe sequences confirmed that the sequences of these probes did not perfectly match the sequences of some marine clones in their respective groups. The sequences of clone env.agg41 in the Cytophaga-Flavobacterium subgroup and clones FL1 and FL11 in the $\alpha$-Proteobacteria subgroup (12), both of which were found in the Santa Barbara Channel near both of our marine sites, did not perfectly match the probe template sequences. The env.agg41 clone sequence had two mismatches (the target sequence had $\mathrm{U}$ instead of $\mathrm{G}$ at $E$. coli position 324 and $G$ instead of $A$ at position 326 ) compared with the $\mathrm{CF}$ probe sequence, while the sequences of the $\alpha$-Proteobacteria clones each had a single mismatch (U instead of A at E. coli position 596) compared with the $\alpha$ PRT probe sequence. Hence, it is possible that the total $\alpha$-Proteobacteria and Cytophaga-Flavobacterium populations may have been underestimated.

For our calculations, autofluorescent cell counts were not subtracted from the probe counts for the marine samples since autofluorescent cells were most likely cyanobacteria or prochlorophytes and, overall, represented less than $5 \%$ of the DAPI counts based on the NP results. The fluorescence of autofluorescent cells (like Synechococcus and Prochlorococcus cells) tends to overlap the fluorescence of the Cy3 dye coupled to the probe. Therefore, autofluorescent cell counts were included in the probe counts. However, since autofluorescent cells did not seem to take up ${ }^{3} \mathrm{H}$-amino acids, they usually did not contribute to the probe counts plus autoradiography counts, so that the latter counts were always lower in our samples.

The average difference between the probe plus autoradiography counts and the probe counts alone for the Catalina Island and San Pedro Channel samples combined showed that nearly $6 \%$ of the cells labeled with the probes were unaccounted for in the probe plus autoradiography counts. In addition, the overall average percentage for autofluorescent cells based on the NP counts for these two samples was $3 \%$. Hence, the data suggest that a small portion $(<10 \%)$ of the cells in each probe group were inactive or took up amino acids very slowly and were not detected autoradiographically.

We suggest the following name for our triple-labeling technique: substrate-tracking autoradiography fluorescent in situ hybridization (STARFISH), since it is an expansion of the FISH technique. To the best of our knowledge, this is the first time that FISH has been used to aid in the identification of an organism in combination with autoradiography. Autoradiography has been used to study the function of microbes in situ for 
a long time (9). In previous studies, however, either the organisms of interest (usually limited to a few species) were identifiable by their morphological features (11) or the entire prokaryotic community was studied as a group that was considered homogeneous both in terms of composition and in terms of function in the uptake of DOM $(15,24,31,40)$.

Perhaps due to the unspecialized ${ }^{3} \mathrm{H}$-amino acid mixture and the general group probes used in our experiments, our results showed that the $\alpha$-Proteobacteria and the Cytophaga-Flavobacterium subgroups had very similar percentages of cells $(80 \%)$ involved in uptake of amino acids. Nevertheless, because the members of the $\alpha$-Proteobacteria were $10 \%$ more abundant, their overall significance in DOM uptake may be greater than the significance of members of the Cytophaga-Flavobacterium group, assuming that the average amount of amino acid taken up per cell does not vary significantly between these two prokaryotic subgroups. With further investigation, STARFISH may help break down the bacterioplankton black box into smaller components and may provide a better understanding of the ecological role of various organisms in the uptake of DOM under natural conditions.

\section{ACKNOWLEGMENTS}

We are grateful to Markus Karner for help with the initial ideas used in this work; to Louis Bergquist and Martin Huh for the culture strains; to Joel Mefford for suggesting the acronym STARFISH; to Rachel Noble and Alison Davis for reviews and comments; to ZhongDong Huang, Steffanie Gehret, Ximena Hernandez, Julian Herndon, Corey Blake, Albert Perdon, Truc Luu, and Liam Carr for help with various parts of the experiments; to the crew members of the R/V Sea Watch and R/V Yellow Fin; and to workers at the Southern California Marine Institute for sample collection. Special thanks go to Marilene Demasi and Scott Robinson for their support and advice.

This research was funded in part by the USC Sea Grant Program, National Oceanic and Atmospheric Association, under grant NA 86 RG 0054 and by the California State Resources Agency. The other portion of this project was funded by grants OCE 9634028 and DEB 9705523 from the National Science Foundation and by a John and Alice Tyler Environmental Scholarship.

\section{REFERENCES}

1. Amann, R. I., B. J. Binder, R. J. Olson, S. W. Chisholm, R. Devereux, and D. A. Stahl. 1990. Combination of 16S rRNA-targeted oligonucleotide probes with flow cytometry for analyzing mixed microbial populations. Appl. Environ. Microbiol. 56:1919-1925.

2. Amann, R. I., L. Krumholz, and D. A. Stahl. 1990. Fluorescent-oligonucleotide probing of whole cells for determinative, phylogenetic, and evironmental studies in microbiology. J. Bacteriol. 172:762-770.

3. Amann, R. I., W. Ludwig, and K. Schleifer. 1995. Phylogenetic identification and in situ detection of individual microbial cells without cultivation. Microbiol. Rev. 59:143-169.

4. Amann, R. I., J. Stromley, R. Devereux, R. Key, and D. A. Stahl. 1992. Molecular and microscopic identification of sulfate-reducing bacteria in multispecies biofilms. Appl. Environ. Microbiol. 58:614-623.

5. Angert, E. R., K. D. Clements, and N. R. Pace. 1993. The largest bacterium. Nature 362:239-241.

6. Azam, F., T. Fenchel, J. G. Field, J. S. Gray, L. A. Meyer-Reil, and F. Thingstad. 1983. The ecological role of water-column microbes in the sea. Mar. Ecol. Prog. Ser. 10:257-263.

7. Azam, F., D. C. Smith, G. F. Stewart, and Å. Hagström. 1993. Bacteriaorganic matter coupling and its significance for oceanic carbon cycling. Microb. Ecol. 28:167-179.

8. Braun-Howland, E. B., S. A. Danielsen, and S. A. Nierzwicki-Bauer. 1992. Development of a rapid method for detecting bacterial cells in situ using $16 \mathrm{~S}$ rRNA-targeted probes. BioTechniques 13:928-933.

9. Brock, T. D., and M. L. Brock. 1966. Autoradiography as a tool in microbial ecology. Nature 209:734-736.

9a.Brunk, C. Personal communication.

10. Brunk, C. F., E. Avaniss-Aghajani, and C. A. Brunk. 1996. A computer analysis of primer and probe hybridization potential with bacterial smallsubunit rRNA sequences. Appl. Environ. Microbiol. 62:872-879.

11. Carman, K. R. 1990. Radioactive labeling of a natural assemblage of marine sedimentary bacteria and microalgae for trophic studies: an autoradio- graphic study. Microb. Ecol. 19:279-290.

12. DeLong, E. F., D. G. Franks, and A. L. Alldredge. 1993. Phylogenetic diversity of aggregate-attached vs. free-living marine bacterial assemblages. Limnol. Oceanogr. 38:924-934.

13. DeLong, E. F., G. S. Wickham, and N. R. Pace. 1989. Phylogenetic stains: ribosomal RNA-based probes for the identification of single cells. Science 243:1360-1363.

14. Fuhrman, J. A. 1992. Bacterioplankton roles in cycling or organic matter: the microbial food web, p. 361-383. In P. G. Falkowski and A. D. Woodhead (ed.), Primary productivity and biogeochemical cycles in the sea. Plenum Press, New York, N.Y.

15. Fuhrman, J. A., and F. Azam. 1982. Thymidine incorporation as a measure of heterotrophic bacterioplankton production in marine surface waters: evaluation and field results. Mar. Biol. 66:109-120.

16. Fuhrman, J. A., S. H. Lee, Y. Masuchi, A. A. Davis, and R. M. Wilcox. 1994. Characterization of marine prokaryotic communities via DNA and RNA. Microb. Ecol. 28:133-145.

17. Fuhrman, J. A., and C. C. Ouverney. 1998. Marine microbial diversity studied via $16 \mathrm{~S}$ rRNA sequences: coastal cloning results and counting of native archaea with fluorescent single cell probes. Aquat. Ecol. 32:3-15.

18. Giovannoni, S. J., E. F. DeLong, G. J. Olsen, and N. R. Pace. 1988. Phylogenetic group-specific oligodeoxynucleotide probes for identification of single microbial cells. J. Bacteriol. 170:720-726.

19. Glöckner, F. O., R. Amann, A. Alfreider, J. Pernthaler, R. Psenner, K. Trebesius, and K.-H. Schleifer. 1996. An in situ hybridization protocol for detection and identification of planktonic bacteria. Syst. Appl. Microbiol. 19:403-406

20. Hagström, Å., U. Larsson, P. Horstedt, and S. Normark. 1979. Frequency of dividing cells, a new approach to the determination of bacterial growth rates in aquatic environments. Appl. Environ. Microbiol. 37:805-812.

21. Hicks, R. E., R. I. Amann, and D. A. Stahl. 1992. Dual staining of natural bacterioplankton with 4',6-diamidino-2-phenylindole and fluorescent oligonucleotide probes targeting kingdom-level 16S rRNA sequences. Appl. Environ. Microbiol. 58:2158-2163.

22. Holt, J. G., N. R. Krieg, P. H. A. Sneath, J. T. Staley, and S. T. Williams 1994. Bergey's manual of determinative bacteriology, 9th ed. Williams \& Wilkins, Baltimore, Md.

23. Hsu, D., L. Shih, and Y. C. Zee. 1994. Degradation of rRNA in Salmonella strains: a novel mechanism to regulate the concentrations of rRNA and ribosomes. J. Bacteriol. 176:4761-4765.

24. Karner, M., and J. A. Fuhrman. 1997. Determination of active marine bacterioplankton: a comparison of universal 16S rRNA probes, autoradiography, and nucleoid staining. Appl. Environ. Microbiol. 63:1208-1213.

24a.Lane, D. J., B. Pace, G. J. Olsen, D. A. Stahl, and M. L. Sogin, and N. R. Pace. 1985. Rapid determination of 16S ribosomal RNA sequences for phylogenetic analyses. Proc. Natl. Acad. Sci. USA 82:6955-6959.

25. Lee, S., and P. F. Kemp. 1994. Single-cell RNA content of natural marine planktonic bacteria measured by hybridization with multiple 16S rRNAtargeted fluorescent probes. Limnol. Oceanogr. 39:869-879.

26. Maidak, B. L., G. J. Olsen, N. Larsen, R. Overbeek, M. J. McCaughey, K. Fogel, and C. R. Woese. 1997. The RDP (Ribosomal Data Project). Nucleic Acids Res. 25:109-111.

27. Maniatis, T., E. F. Fritsch, and J. Sambrook. 1982. Molecular cloning: a laboratory manual. Cold Spring Harbor Laboratory, Cold Spring Harbor, N.Y.

28. Manz, W., R. Amann, W. Ludwig, M. Vancanneyt, and K.-H. Schleifer. 1996. Application of a suite of $16 \mathrm{~S}$ rRNA-specific oligonucleotide probes designed to investigate bacteria of the phylum Cytophaga-Flavobacter-Bacteroides in the natural environment. Microbiology 142:1097-1106.

29. Manz, W., R. Amann, W. Ludwig, M. Wagner, and K.-H. Schleifer. 1992. Phylogenetic oligodeoxynucleotide probes for the major subclasses of proteobacteria: problems and solutions. Syst. Appl. Microbiol. 15:593-600.

30. Massana, R., A. E. Murray, C. M. Preston, and E. F. DeLong. 1997. Vertical distribution and phylogenetic characterization of marine planktonic Archaea in the Santa Barbara Channel. Appl. Environ. Microbiol. 63:50-56.

31. Novitsky, J. A. 1983. Heterotrophic activity throughout a vertical profile of seawater and sediment in Halifax Harbor, Canada. Appl. Environ. Microbiol. 45:1753-1760.

31a.Oligonucleotide Probe Database Website. [Online.] http://www.cme.msu .edu/OPD.

32. Ouverney, C. C., and J. A. Fuhrman. 1997. Increase in fluorescence intensity of 16S rRNA in situ hybridization in natural samples treated with chloramphenicol. Appl. Environ. Microbiol. 63:2735-2740.

33. Pace, N. R., D. A. Stahl, D. L. Lane, and G. J. Olsen. 1986. The analysis of natural microbial populations by rRNA sequences. Adv. Microb. Ecol. 9:155.

34. Porter, K. G., and Y. S. Feig. 1980. The use of DAPI for identifying and counting aquatic microflora. Limnol. Oceanogr. 25:943-948.

35. Preston, C. M., K. Y. Wu, T. F. Molinski, and E. F. DeLong. 1996. A psychrophilic crenarchaeon inhabits a marine sponge: Cenarchaeum symbiosum gen. nov., sp. nov. Proc. Natl. Acad. Sci. USA 93:6241-6246.

36. Rehnstam, A. S., S. Backman, D. C. Smith, F. Azam, and A. Hagström. 1993. 
Bloom of sequence-specific culturable bacteria in the sea. FEMS Microbiol. Ecol. 102:161-166.

37. Salama, M., W. Sandine, and S. Giovannoni. 1991. Development and application of oligonucleotide probes for identification of Lactococcus lactis subsp. cremoris. Appl. Environ. Microbiol. 57:1313-1318.

38. Simon, M. 1985. Specific uptake rates of amino acids by attached and free-living bacteria in a mesotrophic lake. Appl. Environ. Microbiol. 49: 1254-1259.

39. Staley, J. T., and A. Konopka. 1985. Measurement of in situ activities of nonphotosynthetic microorganisms in aquatic and terrestrial habitats. Annu. Rev. Microbiol. 39:321-346.

40. Tabor, P. S., and R. A. Neihof. 1984. Direct determination of activities for microorganisms of Chesapeake Bay populations. Appl. Environ. Microbiol. 48:1012-1019.

41. Tabor, P. S., and R. A. Neihof. 1982. Improved microautoradiographic method to determine individual microorganisms active in substrate uptake in natural waters. Appl. Environ. Microbiol. 44:945-953.

42. Wagner, M., R. Erhart, W. Manz, R. Amann, H. Lemmer, D. Wedi, and K.-H. Schleifer. 1994. Development of an rRNA-targeted oligonucleotide probe specific for the genus Acinetobacter and its application for in situ monitoring in activated sludge. Appl. Environ. Microbiol. 60:792-800.

43. Zweifel, U. L., and A. Hagstrom. 1995. Total counts of marine bacteria include a large fraction of non-nucleoid-containing bacteria (ghosts). Appl. Environ. Microbiol. 61:2180-2185. 